\title{
The Mediating Effects of Feedback and Procedural Justice on the Relationship between Formal Performance Evaluation System and Trust between Superior and Subordinate Managers
}

\author{
Ria Nelly Sari \\ Rita Anugerah \\ Yusralaini \\ Herra Gusrifan \\ Department of Accounting, Faculty of Economics, Universitas Riau, \\ Kampus Bina Widya, KM 12,5 SP Panam, Pekanbaru 28293, Riau, Indonesia \\ Email: ria_n_sari@yahoo.com
}

\section{Doi:10.5901/mjss.2013.v4n10p497}

\section{Abstract}

Trust is an important aspect of social interaction, especially in the workplace. Trust between superiors and subordinates may allow increasing cooperation and information dissemination between subordinates and superiors. Eventhough the superior has trust in his/her subordinates, trust alone is not enough to ensure that the work will reach the target without further scrutiny. Therefore, a monitoring and evaluation mechanism should exist to formally monitor the performance of subordinates. With the performance evaluation, the extent to which performance is achieved can be compared to the set target. This study examines the mediating effect of feedback and procedural justice on the relationship between formal performance evaluation system and trust between superior and subordinate managers. We argue that the application of formal performance evaluation system will enhance trust between superior and subordinate managers through feedback and procedural justice.Using Partial Least Squares (PLS) as an analitycal method, 93 responses from managers of Banks in Pekanbaru, Riau, Indonesia, were analyzed. The findings of this study appear to support the significant role of feedback and procedural justice on trust between superior and subordinate.

Keywords: formal performance evaluation system, feedback, procedural justice, trust, Partial Least Square (PLS), Indonesia.

\section{Introduction}

Some studies of human resources explained that trust is an important aspect of social interaction, especially in the work environment. Interpersonal trust is necessary in order to support the success of the organization in achieving its vision, mission and goals of the organization (Zaheer, McEvily, \& Perrone, 1998). Interpersonal trust is important, especially in the relationship between superior and subordinate managers. It can increase cooperation and then reduce agency problems (Jones, 1995). Trust between superior and subordinate managers enhancing collaboration and information flow between superior and subordinate managers (Spreitzer \& Mishra, 1999) and also can reduce opportunistic behavior (Fisher et al. 2005).

Although trust between superior and subordinate managers already exist, but to ensure that subordinates have been working on target and to control their behavior, superior need a performance evaluation system to evaluate the performance of their subordinates. Performance evaluation that conducted by superiors to subordinates can be done by using a subjective or objective performance evaluation system. Both types of performance evaluation have different effects on trust between subordinates and superiors. Study conducted by Moers (2005) found that subjective performance measures lead to decreased trust among subordinates to superiors. In contrast, study by Hopwood (1972), Tenbrunsel and Messick (1999), Lau and Buckland (2001), and Colleti, Sedatole and Towry (2005) found a positive effect of trust in the use of more objective performance evaluation system.

Hartmann and Slapnicar (2009) developed and tested the model of the relationship between formal performance evaluation system and trust. Findings of their study not only supports the results of previous studies on the positive 
effects of formal (objective) performance evaluation on trust, but they also conclude that the use of formal performance evaluation system can inflluence the trust between superior and subordinates through feedback and procedural justice.

Based on the above explanation, the results of previous studies on the relationship between performance measurement on trust between superiors and subordinates are still not consistent. The aim of this research is to examine the mediating effect of feedback and procedural justice on the relationship of formal performance evaluation system and interpersonal trust. The result is expected to clarify the role of the performance measurement on trust between superiors and subordinates. In addition, previous research related to performance measurement and trust mostly done in western countries. Therefore, a research on performance evaluation especially, formal performance evaluation, and its relationship to trust between superior and subordinates is need to be done in different country in order to get a better understanding about this phenomena.

The remainder of the paper is structured as follows. Section 2 provides an overview of the previous research and hypotheses development. Section 3 presents the design of the emperical survey that conducted. The results from the tests of hypotheses are presented in section 4. Last section of this paper, Section 5, present the discussion and conclusions of this study.

\section{Literature Review and Hypotheses Development}

\subsection{Formal Performance Evaluation System and Trust}

Formal performance evaluation is a systematic study that shows the objective conditions and employee's performance in achieving the goals set by the company. Formal performance evaluation is an assessment that conducted formally and associated with predetermined company's work standards. Furthermore, formal performance evaluation is also associated with the assessment that carried out by using the measures and principles that have been established by companies such as regulations and format and system that consist of a number of elements that are interconnected and which need interrelated steps in its implementation.

Studies on the relationship between performance evaluation and trust between superiors and subordinates have been done by previous researchers. Previous study conducted by Hopwood (1972) showed the important role played by the budget. Budget is categorized as financial - objective performance measurement. Respondents in this study showed a high level of trust when their superiors use the budget as a basis for evaluating their performance. Similar finding also found in Hartmann and Slapnicar (2009). Hartmann and Slapnicar (2009) found that the use of formal performance evaluation system will have a positive effect on trust between superior and subordinate. Superiors who use performance evaluation in a formal way are those superiors that explain performance targets, measure the performance of their subordinates based on a clear metrics and reward their subordinates based on clear allocation rules. This process will lead to an increase in the level of integrity, honesty, accuracy and consistency in performance evaluation.

Lau and Buckland (2001) found that trust between superior and subordinate is increased when superior uses financial measures which are more objective for evaluating subordinates' performance. While research conducted by Lau and Sholihin (2005) reported that the level of trust increases when top-level managers use non-financial performance measurements that are said to have 'a larger scope' and 'more complete'.

Tenbrunsel and Messick (1999) suggests that formal performance appraisal system allows a decrease in the level of trust among individuals. In contrast, Colleti et al (2005) found a positive effect of trust in the use of formal performance evaluation system. They argue that the performance appraisal system is important in an effort to get feedback, so as to improve managerial performance. The above studies show that the performance evaluation system is not only affecting the trust, but also raises questions whether subjective or formal performance evaluation systems could affect the level of trust between managers and subordinates. The arguments and evidences mention above lead to hypothesis:

$\mathrm{H} 1$ : The use of formal performance evaluation system is positively related to trust between superior and subordinate managers.

\subsection{Formal Performance Evaluation System, Trust and Feedback}

According to Colleti, Sedatole and Towry (2005) and Lau and Buckland (2001), performance evaluation conducted by superiors to subordinates is associated with feedback. Performance feedback is defined as the feedback that received by subordinates for their performance achievement (Steelmann et al., 2004). Feedback is essential since feedback 
increased subordinates' understanding about their performance and will give a chance to subordinates to adjust their behavior to enhance performance (Steelmann et al., 2004).

Lau and Buckland (2001) and Colleti, Sedatole and Towry (2005) provide a view that the effect of a formal performance evaluation system on trust can be attributed to the increased feedback. Effective feedback can occur when performance evaluation is based on targets that have clearly defined, is done accurately and in a way that is understood by subordinate. In addition, rewards are distributed in a transparent and traceable. All of the dimentions mention above are the dimention of formal performance evaluation system. Therefore the use of formal performance evaluation by superior to subordinates will lead to increased feedback. Furthermore feedback that received by subordinates will increase the trust between subordinates and superior since subordinates perceive that their superior attempt to provide good feedback in order to improve subodinates' performance and improve their working relationship. Based on arguments above, it can be concluded that feedback has a role as a link between the formal performance measurement and trust between superiors and subordinates. Hartmann and Slapnicar (2009) in their study have proved that feedback is a mediating variable that mediates the relationship between formal performance evaluation and trust. The arguments and evidence lead to the following hypothesis:

$\mathrm{H} 2$ : The relationship between formal performance evaluation system and trust between superior and subordinate managers is mediated by feedback

\subsection{Formal Performance Evaluation Systems, Trust and Procedural Justice}

According to Leventhal (1976), the decision makers must adhere to social norms such as consistency, honesty and accuracy to enhance the procedural fairness of the decision making processes they engage in. Therefore, when superior uphold social norms such as honesty, accuracy and consistency in evaluating the performance of subordinates, the procedural justice will enhance and then the level of trust between subordinates to their superior will also increase.

The use of formal performance evaluation systems conducted by superior in a proper manner and in accordance with established procedures and rules, will increase the confidence of subordinates that their performance have been assessed fairly and objectively. This situation will lead to increased subordinates' perceptions on procedural justice and then trust. Dirks and Ferrin (2002) have proved the existence of a positive relationship between procedural justice and trust. Findings of Dirks and Ferrin (2002) was then supported by Hartmann and Slapnicar (2009) which not only proved that the existence of a positive relationship between procedural fairness and trust, but also proved the role of procedural justice as a mediating variable that links between formal performance measurement and trust between superior and subordinates. These arguments and evidence lead to the following hypothesis:

H3: The relationship between formal performance evaluation systems and trust between superior and subordinates managers is mediated by procedural justice.

\section{Research Method}

\subsection{Sample}

We conducted a survey study among middle managers in banking industry in Pekanbaru, Riau, Indonesia. To get high response rate, a total of 144 questionnaires were distributed by hand delivered to the targeted respondents. Of the 144 questionnaire distributed, 101 were returned representing a response rate of $70.13 \%$. However, due to some left information, 8 set questionnaires were dropped. 21 HRD managers, 14 operational managers, 32 marketing managers and 26 finance managers from 32 banks (66.67\%) were participate in this study. Demografic information was collected regarding age, gender, education background, job tenure, and job position.

\subsection{Operationalization of Variables}

\subsubsection{Formal Performance Evaluation Systems}

Formal performance evaluation system is defined as a system to evaluate and assess the performance of employee that is conducted formally and objectively. Formal performance evaluation system is a construct that consist of 3 indicators: target setting, performance measurement and rewarding (Hartman and Slapnicar, 2009). Formal performance evaluation system is measured using a 6 items instrument adopted from Hartman and Slapnicar (2009). The respondents were 
asked to indicate the extent to which performance targets are explicity documented in a written form and the extent to which targets are quantified. The respondents also were asked to rate the extent to which the superior relies on objective information from the information system and the extent to which respondents' evaluation is express in quatative term. The last two items of this instrument address the questions whether reward are based on objective information from the system and whether reward are based on quantitative terms. For all six items, respondents were asked to indicate their agreement on the statement presented on a 7-point Likert scale ranging from 1 (strongly disagree) to 7 (strongly agree) . Sample items include "When establishing work objective, my superior explicitly documents these objectives in writing" and "when judging my performance, my superior relies on objective information from the information system" .

\subsubsection{Trust}

Following Hartmann and Slapnicar (2009), in this study trust is defined as the extent to which subordinate managers perceive that their superior is inclined to take actions that are in the interest of them. Trust is measured using a 3 items instrument adapted from Read (1962) and Hartmann and Slapnicar (2009). The respondents were asked to express the extent to which their superiors are likely to take action that are in their interest by using a Likert-type scale ranging from 1 (strongly disagree) to 7 (strongly agree). Sample items include "My superior will always act in my favor if he has the chance " and "I am convinced that my superior will always fully and honestly keep me up to date of everything that is important to me".

\subsubsection{Feedback}

Feedback is defined as the extent to which the feedback that given by a superiors are perceived useful by subordinate managers in improving their performance. Feedback is measured using a 4 items instrument developed by Steelman et. al (2004). For all 4 items, respondents were asked to indicate on a 7 point Likert scale ranging from 1 (strongly disagree) to 7 (strongly agree). A sample item is "My superior gives me useful feedback about my job performance".

\subsubsection{Procedural Justice}

Procedural justice is defined as the extent to which respondents believe that the subsytem of target setting, performance measurement and rewarding system in total leads to a fair determination of pay (Hartman and Slapnicar 2009). Procedural Justice is measured using a 4 items instrument adopted from Hartman and Slapnicar (2009). Measurement of this variable also uses the 7-point Likert scale, where $1=$ strongly disagree, $4=$ neutral, $7=$ strongly agree. A sample item is "I have full confidence in the system's fairness in determining pay".

\subsection{Data Analysis}

In this study the data were analyzed by using the Partial Least Square (PLS) approach, using Smart PLS software. PLS is a structural equation model (SEM) of component-based or variance-based. PLS is an alternative approach that shifts from covariance-based SEM approach to variance-based SEM. Covariance-based SEM generally examine causality or theory, while PLS is more predictive models (Ghozali, 2006). PLS is a powerful analytical method (Wold, 1985). PLS is not based on many assumptions such as normality of data and large data samples. PLS can be used on small data samples, and can be used on data that are not normally distributed.

The application of PLS model is done in two steps. Firstly, the assessement of measurement by assessing the reability and validity of the scale measure. Secondly the structural model was used in testing the hypotheses proposed. This procedure was done sequencely to ensure that the measurement of construct is reliable and valid before any attempt is made to draw conclusions about the nature of relationship among contruct (Hulland, 1999).

\section{Results}

\subsection{Measurement Model}

Before the assessment of the structural model is done, the quality of measurement model was assessed. The quality of measurement model was assessed by addressing individual item reliability, construct liability, and convergent and 
discriminant validity (Ghozali, 2006)

Statistics from the PLS measurement models are used to examine the convergent validity of the model by examining the factor loading. The factor loading from the final PLS measurement model is reported in Table 1. Factors loading of all items of the model are greater than 0.5 and are significant at $p<0.05$ (two tail; $t>1.96$ ). However, two items from formal performance evaluation have factor loading below 0.5 (Item 1 and 4) A low item loading adds very little to the explanatory power of the model and potentially biases the estimate of parameters linking the constructs (Chin, 1998; Hulland, 1999). As such, those items are removed from the scale and are not included for further analysis. The result demonstrates an acceptable convergent validity (Tabel 1).

Tabel 1. Resuls for Outer Loading

\begin{tabular}{|l|c|c|c|c|}
\hline & $\begin{array}{c}\text { Original sample } \\
\text { estimate }\end{array}$ & $\begin{array}{c}\text { Mean of sub } \\
\text { samples }\end{array}$ & $\begin{array}{c}\text { Standard } \\
\text { deviation }\end{array}$ & T statistic \\
\hline Formal Performal Evaluation System: & & & & \\
\hline Item2 & 0.734 & 0.719 & 0.107 & 6.832 \\
\hline Item3 & 0.604 & 0.611 & 0.146 & 4.148 \\
\hline Item5 & 0.616 & 0.650 & 0.135 & 4.557 \\
\hline Item6 & 0.709 & 0.661 & 0.238 & 2.983 \\
\hline Trust between Superior and Subordinates: & & & & \\
\hline Trust 1 & 0.818 & 0.786 & 0.155 & 5.274 \\
\hline Trust2 & 0.868 & 0.862 & 0.053 & 16.532 \\
\hline Trust3 & 0.874 & 0.875 & 0.043 & 20.263 \\
\hline Feedback: & & & & \\
\hline Feedback1 & 0.860 & 0.855 & 0.054 & 16.056 \\
\hline Feedback2 & 0.706 & 0.666 & 0.112 & 6.291 \\
\hline Feedback3 & 0.736 & 0.722 & 0.128 & 5.734 \\
\hline Feedback4 & 0.680 & 0.698 & 0.149 & 4.575 \\
\hline Procedural Justice: & & & & \\
\hline Procedural Justice1 & 0.833 & 0.819 & 0.051 & 16.403 \\
\hline Procedural Justice2 & 0.850 & 0.844 & 0.046 & 18.514 \\
\hline Prpcedural Justice3 & 0.860 & 0.853 & 0.059 & 14.642 \\
\hline Prpcedural Justice4 & 0.832 & 0.822 & 0.066 & 12.527 \\
\hline
\end{tabular}

Following Fornell and Lacker (1981) the reliability of each variable is assessed based on composite reliability. As shown in column 2 Table 2, the composite reliability for each variable is above 0.70 , which demonstrates that each variable has an acceptable reliability (Nunnally, 1978). The discriminant validity of the measurement model is assessed based on the square root of average variance extracted (AVE) as compared to the correlations among the latent variables (Chin, 1998). This provides a test on the extent to which a construct shares more variance with its measure than it shares with other constructs. Table 2 shows that the square roots of the AVEs (diagonal) are all greater than the respective correlations between constructs.

Table 2. Composite Reliability and Average Variance Extracted (AVE) Statistics, and Correlation from PLS Model

\begin{tabular}{|c|c|c|c|c|c|c|}
\hline \multirow{2}{*}{ Variable } & \multirow{2}{*}{ Composite Reliability } & \multirow{2}{*}{ AVE } & \multicolumn{4}{|c|}{ Correlation } \\
\cline { 4 - 7 } & & & FPES & FB & PJ & Trust \\
\hline FPES & 0.762 & 0.446 & 0.668 & & & \\
\hline FB & 0.835 & 0.561 & 0.500 & 0.753 & & \\
\hline PJ & 0.908 & 0.712 & 0.606 & 0.602 & 0.844 & \\
\hline Trust & 0.890 & 0.729 & 0.282 & 0.521 & 0.569 & 0.854 \\
\hline
\end{tabular}

Diagonal elements are the square root of the AVE statistics. Off diagonal elements are the correlations between the latent variables calculated in PLS. FPES= Formal Performance Evaluation Systems; FB= Feedback; PJ= Procedural Justice; Trust= Trust between Superior and Subordinate Managers

Results of the test discussed above demonstrate adequate discriminant validity. Overall, results from the PLS measurement model indicate that each construct exhibits satisfactory reliability and validity. 


\subsection{Test of Hypotheses}

A structural model in PLS was used to test hyphoteses proposed. Tabel 3 presents the results of hypotheses testing. Hypothesis 1 which stated that the use of formal performance evaluation system will be positively related to trust between superior and subodinat managers, was not supported ( $\beta=-0.166, t=0.956, p>0.05)$. Hence $\mathrm{H} 1$ is rejected.

The results shown in Table 3 ilustrates that formal performance evaluation system has direct relationship with feed back $(0.500, p<0.01)$ and procedural justice $(0.606, p<0.01)$. The results also shown that feedback and procedural justice have positive relationship with trust between superior and subordinate managers $(0.13, p<0.05 ; 0.480, p<0.01$ respectively).

The results indicate that feedback and procedural justice mediated the relationship between formal performance evaluation system and trust between superior and subordinate managers. To examine the mediating effect $(\mathrm{H} 2$ and $\mathrm{H} 3)$ a post-hoc Sobel test (sobel 1982) was conducted. The test required running two PLSs model for each mediating variable. The first model included path from independent variable to mediating variable (Model A1 and A2). The second model included the path from mediating variable to dependent variable (Model B1 and B2).

Table 3. Path Coefficients, $t$ Statistics and $R^{2}$

\begin{tabular}{|l|c|c|}
\hline & $\begin{array}{c}\text { Path } \\
\text { coefficient } \beta\end{array}$ & $\mathrm{R}^{2}$ \\
\hline Formal Performance Evaluation Systems $\rightarrow$ Trust between Superior and Subordinate Managers & $-0.166(0.956)$ & \\
\hline Formal Performance Evaluation Systems $\rightarrow$ Feedback & $0.500^{\star \star}(4.737)$ & $0.315^{\star}(1.665)$ \\
\hline Feedback $\rightarrow$ Trust between Superior and Subordinate Managers & $0.606^{\star \star}$ & $(6.298)$ \\
\hline Formal Performance Evaluation Systems $\rightarrow$ Procedural Justice & $0.480^{\star \star}(3.260)$ & \\
\hline Procedural Justice $\rightarrow$ Trust between Superior and Subordinate Managers & & - \\
\hline FPES & & 0.250 \\
\hline FB & & 0.368 \\
\hline PJ & & 0.391 \\
\hline Trust & & \\
\hline
\end{tabular}

$\mathrm{N}=93$; Number in parentheses indicate t-value (one tailed tests); ${ }^{*}<0.05, p^{\star \star}<0.01$

FPES= Formal Performance Evaluation Systems; FB= Feedback; $\mathrm{PJ}=$ Procedural Justice; Trust= Trust between Superior and Subordinate Managers

Tabel 4. Mediation Results

\begin{tabular}{|c|c|c|c|c|c|c|}
\hline & Model A & & Model B & & Sobel Test & $\mathrm{P}$ \\
\hline 1 & Path & $\mathrm{t}$ & Path & $\mathrm{t}$ & & \\
\hline & FPES $\rightarrow$ FB & 5.747 & FB $\rightarrow$ Trust & 3.049 & 5.162 & 0.00 \\
\hline 2 & FPES $\rightarrow$ PJ & 6.845 & PJ $\rightarrow$ Trust & 4.144 & 6.09 & 0.00 \\
\hline
\end{tabular}

Note: FPES= Formal Performance Evaluation Systems; FB= Feedback; PJ= Procedural Justice; Trust= Trust between Superior and Subordinate Managers

The results shown in the final column of the table, demonstrated that the relationship between formal performance evaluation systems and trust between superior and subordinate managers are mediated by feedback (Sobel=5.162, $\mathrm{p}=0.00$ ) and procedural justice (Sobel $=6.06, \mathrm{p}=0.00$ ). Hence $\mathrm{H} 2$ and $\mathrm{H} 3$ are supported.

Results are summarized in figure 1.

\section{Discussion and Conclusion}

The purpose of this paper is to explore the effects of feedback and procedural justice on the relationship between formal performance evaluation systems and trust between superior and subordinate managers. A structural model was tested by using PLS to examine whether the relationship between formal performance evaluation system and trust between superior and subordinates is direct or indirect through the mediating variables of feedback and procedural justice. Results indicate that no direct relationship exists between formal performance evaluation systems and trust between superior and subordiantes. This finding is contrary to 


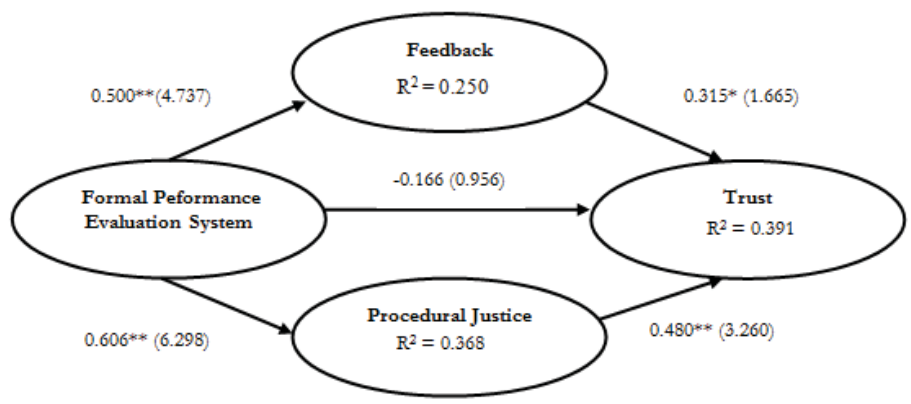

Figure 1. Results of the Relation among Formal Performance Evaluation System, Feedback, Procedural Justice and Trust between Superior and Subordinate

hypothesis proposed $(\mathrm{H} 1)$. The rejection of $\mathrm{H} 1$ indicates the formal performance evaluation system is not directly related to trust between superior and subordinates, rather formal performance evaluation system is indirectly related to trust between superior and subordinates managers through feedback and procedural justice. These results are consistent with Hartmann and Slapnicar (2009).

Results of this study show that formal performance evaluation alone can not guarantee that the subordinates would trust his superiors. To increase the the level of trust between superior and subordinate, the superior must provide quality feedback every time the performance evaluation is done. Quality feedback will lead to subordinates believe that the superior is always be in a position to support the performance of the subordinates. Therefore a good superior should be able to provide quality feedback to subordinates. Another interpretation can also be made from the results of this study. Companies that implement formal evaluation objectively, will encourages subordinates to believe that every decision in the company have been done fairly and transparent.

Although the study has reached its objectives, the findings of the study need to be interpreted with the following study limitations in mind. First, respondents in this study are from banking industry in Indonesia. Therefore, generalization of this study is limited. Future study can replicate this study to other industry to achieve a better generalization of the results. Second, as suggested by Hartmann and Slapnicar (2009) different research design such as experimmental design would broader our understanding about performance evaluation and trust.

\section{References}

Chin, W.W. (1998). The partial least squares approach to structural equation modeling, In G.A. Marcoulides (Ed.) Modern method for business research, pp. 295-236. Mahwah, NJ: Lawrence Erlbaum Associates Publisher.

Colleti, A.L., Sedatole, K.L., \& Towry, K.L. (2005). The effect of conntrol system on trust in collaborataive environment. The Accounting Review, 80, 477-500.

Dirks, K.T., \& Ferrin, D.L. (2002). Trust in leadership: Meta-analytic findings and implications for research and practice. Journal of Applied Psychology, 87, 611-628.

Fisher, J.G., Maines, L.A., Peffer, S.A., \& Sprinkle, G.B., ( 2005). An experimental investigation of employer discreation in employee performance evaluation and compensation. The Accounting Review, 80, 563-583.

Fornell, C., \& Larcker, D.F. (1981). Evaluating structural equation models with unobservable variables and measurement errors. Journal of Marketing Research, 18, 39-50.

Ghozali, I. (2006). Structural equation modeling: Metode alternatif dengan Partial Least Square. Semarang: Badan Penerbit Undip.

Hartmann, F. \& Slapnicar, S. (2009). How formal performance evaluation effects trust between superior and subordinates managers. Accounting, Organization and Society, 34, 722-737.

Hopwood, A.G. (1972). An empirical study of the role of accountin data in performance evaluation. Journal of Accounting Research, 10. 156-182.

Hulland, J. (1999). Use of partial least squares (PLS) in strategic management research: a review of four recent studies, Strategic Management Journal, 20, 195-204.

Jones, T.M. (1995). Instrumental stakeholder theory: A systhesis of ethics and economics. Academy of Management Review, 20, 404437.

Lau, C.M \& Sholihin, M . (2005). Financial and non financial performance measure: How do they effect job satisfaction. British Accounting Review, 37. 389-413. 
Lau, C.M. \& Buckland, C. (2001). Budgeting-Rule of trust and participation: A research note. ABACUS, 37. 369-388.

Leventhal, G.S. (1976). Fairness s social relationships. In J.W. Thibaut, J.T. Spence, \& R.C. Carson (Eds.). Contempory topics in social psychology (pp. 211-239). Morristown, New York: General Learning Press.

Moers, F. (2005). Discreation and bias in performance evaluation: The impact of diversity and subjectivity. Accounting, Organization and Society, 30.67-80.

Nunnally, J.C. (1978). Psychometric theory. New York: McGraw Hill Book Company.

Read, W.H. (1962). Upward communication in industrial hierarchies. Human Relations, 15, 3-15.

Spreitzer, G.M. \& Mishra, A.K. 1999). Giving up control without losing control: Trust and its substitutes' effects on managers' involving employees in decision making. Group and Organization Management, 24, 155-187.

Steelmann, L.A., Levy, P.E., Snell, A.F.(2004). The feedback environment scale: Construct definition, measurement and validation. Educational and Psychological Measurement, 64, 165-184.

Tenbrunsel, A.E., \& Messick, D.M. (1999). Sanctioning systems, decision frameworks, and cooperation. Administratite Science Quarterly, 44. 684-707.

Wold, H. (1985). System analysis by partial lest squares, In. P. Nijkamp, H.Leitner and Wrigley (Eds.) Measuring the unmeasurable. Marinus Nijhoff: Dordrecht.

Zaheer, A., McEvily, B. \& Perrone, V.(1998). Does trust matter? Exploring the effects of interorganizational and interpersonal trust on performance. Organization Science, 9, 141-159 